\title{
INSTRUCTION ON METAPHORS During a Study-Abroad Program: STUdents' Perceptions ANd Understandings
}

\author{
LA METÁFORA COMO TEMA DE INSTRUCCIÓN DURANTE UN PROGRAMA DE INTERCAMBIO: \\ PERCEPCIONES Y COMPRENSIONES DE LOS ESTUDIANTES
}

LA MÉTAPHORE COMME SUJET D'ENSEIGNEMENT LORS D'UN VOYAGE D'ÉTUDE À L'ÉTRANGER : Perceptions et COMPRÉHENSIONS

\author{
C. Cecilia Tocaimaza-Hatch \\ Ph. D. in Hispanic Linguistics, The \\ University of Texas at Austin, TX, USA. \\ Associate Professor, Foreign \\ Languages and Literature, University \\ of Nebraska at Omaha, NE, USA. \\ ctocaimazahatch@unomaha.edu \\ https://orcid. \\ org/0000-0002-0391-5818
}

\begin{abstract}
It has been observed that language learners struggle to gain access to the metaphorical structures that are part of the target language and culture. In this study, six Spanish L2 learners and nine Spanish heritage speakers from the United States completed a study abroad program in Spain in which language instruction was supplemented with a module on the subject of metaphors. This article seeks to describe this module and present learners' perceptions of its implementation and of the learnings resulting from it, as reflected in learners' weekly reflections and exit questionnaire. The analysis of these data indicated that most participants became aware of metaphors in every-day language. However, they were not fully able to produce metaphors themselves. Pedagogical implications of this experience include differentiated metaphor instruction for heritage speakers and L2 learners, and fostering not just metaphor awareness but competence.
\end{abstract}

Keywords: metaphor instruction; students' perceptions; study abroad; heritage speakers; Spanish as a second language.

\section{RESUMEN}

Se ha observado que a los estudiantes de idiomas se les dificulta comprender y utilizar las estructuras metafóricas que hacen parte de la lengua y la cultura de la lengua de estudio. En esta investigación, un grupo de aprendices de español, que incluyó seis estudiantes de español como segunda lengua y nueve hablantes de español como lengua de herencia originarios de EE. UU., participó en un programa de intercambio en España cuyo currículo incluyó un módulo sobre el uso de las metáforas. En este artículo se describe este módulo de enseñanza y se presentan tanto las percepciones de los estudiantes sobre el módulo como los aprendizajes derivados de él. Los resultados se obtuvieron en base a dos fuentes: reflexiones semanales de los participantes y un cuestionario que completaron al finalizar el curso. Estos datos señalan que la mayoría de los participantes logró entender las metáforas utilizadas en el día a día. Sin embargo, aún no se sentían capaces de producir las metáforas ellos mismos. Las implicaciones pedagógicas de esta

Received: 2019-11-19 / Accepted: 2020-04-21 / Published: 2020-09-17

https:/doi.org/10.17533/udea.ikala.v25n03a08 
experiencia se refieren a la instrucción diferenciada para estudiantes de español como segunda lengua y para hablantes de español como lengua de herencia.

Palabras clave: metáforas; español como segunda lengua; percepciones de los estudiantes; programas de intercambio; hablantes de herencia.

\section{RÉSUMÉ}

Il a été observé que les apprenants de langue ont du mal à comprendre et à utiliser les figures métaphoriques qui appartiennent à la langue et à la culture étudiées. Dans cette recherche, un groupe d'étudiants, parmis lesquels il y avait six apprenants en espagnol, deuxième langue (L2) et neuf locuteurs de langue d'héritage d'origine des États-Unis participant à un programme d'échange en Espagne. L'enseignement des langues a été complété par un module sur l'utilisation des métaphores. Cet article décrit ce module d'enseignement et examine les perceptions des apprenants sur mise en œuvre et les apprentissages auto-évalués qui en découlent. Les résultats proviennent de deux sources de données: des réflexions hebdomadaires et un questionnaire que les participants ont rempli à la fin du programme. Ces données indiquent que la majorité des participants ont acquis une compréhension des métaphores quotidiennes, mais ils ne se sentaient pas encore capables de produire des métaphores dans leur propre discours. Les implications pédagogiques incluent des suggestions pour différencier l'enseignement de la métaphore pour les locuteurs de langue d'héritage et les apprenants d'espagnol langue seconde.

Mots-clés : métaphores; espagnol langue seconde ; perceptions des apprenants ; programmes d'échange ; locuteur de langue d'héritage. 


\section{Introduction}

Danesi (1995) described the speech of language learners as having an "unnatural degree of 'textbook literalness," and argued that this deficiency stems from not having access to metaphorical structures that occur in the background of the target language and culture. Taking a Vygotskian approach to cognition, deficiencies connected to metaphorical competence suggest that learners lack the broad array of culturally constructed artifacts that native speakers possess and that organize their mental lives (Shore, 1996, as cited in Lantolf 1999). Culturally constructed artifacts, such as gestures, rituals, and metaphors, allow humans to exert mediated action on their surrounding world and are appropriated by native speakers through the activity of living (Lantolf \& Thorne, 2006). Despite the essentialness that the appropriation of cultural constructs has in linguistic development, few investigations have explored this aspect of language learning (Lantolf, 1999).

This article focuses on one cultural artifact: metaphor, which represents concepts that govern human thinking and functioning and make it possible for individuals to understand reality and engage with each other (Lakoff \& Johnson, 2003). It reports on Spanish L2 learners and Spanish heritage speakers (HS) in the US who completed a study abroad (SA) program in Spain in which language instruction was supplemented with a module on the subject of metaphor. The purpose of this article is thus twofold: (a) to describe the instruction module targeting metaphor, and (b) to present learners' perceptions of its implementation and new understanding of metaphor in Spanish as a result of their engagement with metaphor-centered tasks during SA.

The article is divided into four main sections. The first section explains the theoretical framework that supports the investigation of metaphor development in the SA context. This is followed by the methodology, where the module on metaphor is detailed as well as its implementation in a group of learners participating in SA. The data collected from the pedagogical intervention is summarized under the results section. The article concludes with a discussion on its findings and pedagogical implications for teaching and learning metaphor in SA.

\section{Theoretical Framework}

This section defines tenets for the discussion on metaphorical competence drawn from Cognitive Metaphor Theory (Lakoff \& Johnson, 2003), connects metaphor with language learning, and concludes with an examination of learning situated in SA.

\section{Conceptual and Linguistic Metaphors}

Cognitive development is shaped by the appropriation of cultural models (i.e., culturally organized concepts as defined by a sociocultural group), one of them being conceptual metaphors (Lantolf, 1999, Lantolf \& Thorne, 2006). Conceptual metaphors are culturally constructed models that organize experience. They are at the core of everyday mental and linguistic activity and represent ways of thinking in which individuals establish abstract concepts, such as time or emotions, in terms that are more concrete and easily understood (e.g., places or substances; Littlemore \& Low, 2006). Lakoff and Johnson (2003) elaborated this understanding of metaphorical concepts and explored how they structure everyday activity. For instance, linguistic expressions such as "he attacked every weak point of my argument" and "his criticisms were right on target" result from the conceptual metaphor ARGUMENT IS WAR (by convention, conceptual metaphors are written in capital letters). As the authors point out, humans do not simply talk about arguments in terms of war. Rather, the behaviors materialized in an argument are partially constructed by the concept of war: individuals attack their opponent or abandon the argument or verbal battle.

Many conceptual metaphors are universal, while others vary; yet, in other instances, while the same 
conceptual metaphor exists in different cultures, it might be produced linguistically (through linguistic metaphors) in different ways (Littlemore, 2009). For instance, the conceptual metaphor TIME ELAPSING IS TRAVELING is shared by the Anglo and Hispanic cultures. In English, a linguistic metaphor produced on the basis of this conceptual metaphor is "winter is coming." Similarly, in Spanish, it is possible to say "llega el invierno" ("winter is coming"). Conversely, the conceptual metaphor ENVY IS RED results in such expressions as "ponerse rojo de la envidia" ("to turn red with envy") in Spanish, while English connects envy with the color green (Lantolf \& Bobrova, 2014). These examples shed light on the challenges that language learners encounter when learning another language and trying to use and comprehend metaphors.

Because language learning involves "the use of meaning as a way of (re)mediating our psychological, and, by implication, our communicative activity" (Lantolf \& Thorne, 2006, p. 118), prior studies have investigated the learnability of conceptual and linguistic metaphors. For instance, Kövecses and Szabó (1996) and Doiz and Elizari (2013) compared two approaches to conceptual metaphor learning. One involved explanations of target vocabulary and translations while the second condition included explicit instruction on conceptual metaphors. The latter proved to be more effective.

Other researchers have focused on the production of linguistic metaphors. Danesi (1995) presented findings of two studies. In the first one, Italian students of various proficiency levels and Italian students for whom Italian was their native language identified and translated linguistic metaphors. Based on comparisons in performance between groups, the author concluded that metaphorical competence was virtually nonexistent in any of the participants. In a second study with Spanish L2 learners and native speakers, the author analyzed metaphorical density in a writing task. It was found that native speakers produced significantly more linguistic metaphors than L2 learners. In addition, the linguistic metaphors employed by L2 learners were not original but shared with their L1. Lastly, Johnson and Rosano (1993) investigated English L2 learners' ability to interpret linguistic metaphors. The authors considered learners' communicative competence and linguistic proficiency in the analysis and concluded that learners were able to interpret metaphors correctly independently from their L2 proficiency.

Given that metaphor is an essential psychological tool that mediates mental activity, and its appropriation is necessary for linguistic development in language learning, it is important to attend to learners' development of metaphorical competence, both conceptual and linguistic. Furthermore, there is a need to focus on culture in particular, given the way metaphorical competence operates across and within culture (Danesi, 1995). Following this line of thought, the next section introduces culture in language learning; because the current study contextualizes metaphoric knowledge within the SA setting, the discussion is framed within that context.

\section{Culture, Language, and Study Abroad}

Traditionally, culture was perceived merely as information regarding the arts, literature, and history associated with the target language. More recently, though, culture has begun to be understood as a "membership in a discourse community that shares a common social space and history, and common imaginings" (Kramsch, 1998, p. 10). With these changes, the teaching of culture evolved from a presentation of facts to a focus on meanings and an understanding on how culture is an intricate component of one's and others' language (Koike \& Lacorte, 2014).

The SA context appears to provide a prime setting for learners to access the target culture and participate in the discourse community. However, 
students are not always able to fully integrate: Some learners struggle to be removed from their comfort zone while others resist participating in the new community or withdraw from it (Strange \& Gibson, 2017). Yet, in other instances, the language community might reject or marginalize learners (Wang, 2010). Therefore, although SA might appear as an ideal learning context, numerous variables converge into creating a more or less favorable learning setting.

In this complex language learning setting that constitutes SA, researchers have explored learners' ability to participate in the discourse community. One means of exploration has been through the study of specific linguistic forms. Reynolds-Case (2013) investigated learners' comprehension and production of the Spanish second-person plural vosotros pronoun. Data sources included observations of learners' everyday interactions with members of the target culture. The analysis demonstrated an increase in learners' appropriate use of vosotros. Reynolds-Case concluded that SA was effective in framing learners' cultural and linguistic outcomes regarding the use of vosotros, even without explicit instruction. Nguyen and Kellogg (2010) traced English L2 students' changing understanding of the culturally rich word stereotype. Learners' and the teacher's participation in class activities was analyzed, which showed how learners' understanding of the target item developed as they negotiated stances toward dicussion topics and drew from their own understanding and experiences. Nguyen and Kellogg explained that the learning of the meanings of the linguistic form resulted from learners' acquisition not only of the linguistic form but also the ways of thinking and behaving of the language community.

Thus, these studies suggest that learners are able to grasp linguistic forms and develop an understanding of their culturally appropriate use. On the other hand, and as reported in the previous section, studies on the learnability of metaphor have shed light on the challenge of appropriating the target language's conceptual and linguistic metaphors. Indeed, it has been concluded that the learnability of metaphor is a complex matter, and it is not yet known how metaphorical competence can be built or taught. Nevertheless, it has also been suggested that if learners show control of linguistic metaphors, the possibility exists that they have appropriated the conceptual metaphor behind them; conversely, if learners show no understanding of linguistic metaphors, most likely they have no understanding of their underlying conceptual metaphors (Lantolf, 2006). In other words, controlling linguistic metaphors might be a path toward developing conceptual metaphors of the target language, and vice versa. Based on these premises, this article has two objectives: first, to describe a module for the teaching of metaphor based on the recommendations by Lantolf and Bobrova (2014) on metaphor instruction; and, second, to examine its efficacy as part of language instruction during a study abroad program, as seen from the learners' perspective.

\section{Method}

This section provides information on how participants were instructed on the subject of metaphor. It also provides a description of participants, their proficiency levels, and a report of their activities in the target language while abroad. Lastly, a description of data sources and the analysis implemented to gather learners' perceptions and self-assessments are detailed. It is worth noting that all research activities described in this investigation had approval and oversight from the institutional review board of the researcher's employing university to protect human research subjects. Prior to any activities pertaining to this study, the researcher discussed the project with students, who then signed a consent form confirming their participation. In the implementation of the procedures detailed in this article, all regulations pertaining to research involving human subjects were followed. 


\section{Metaphor Instruction}

Instruction on the subject of conceptual and linguistic metaphor was built on the recommendations by Lantolf and Bobrova (2014). The authors asserted that learners should be able to "recognize metaphors, to identify basic experiences in terms of which abstract phenomena (e.g., time, love, life, etc.) are conceptualized in the L2, and to imbue their own L2 discourse with conceptually appropriate metaphors" (p. 52). They stated that building metaphorical competence requires that metaphorical structures be made accessible, learners' attention be drawn to them, and the conceptual structure underneath the linguistic metaphor be explained. They also suggested cross-culture and cross-linguistic comparisons between learners' L1 and L2.

Table 1 presents an overview of the culture module implemented in this study broken down into weekly assignments, their pedagogical goals, and tasks. Assignments were defined by (a) simplified theoretical instruction on linguistic metaphors in every-day language and their underlying conceptual metaphors; (b) encouraging learners to look for metaphoric samples in the environment that sA furnished for them (e.g., overhearing native speakers' talk, reading signs); (c) prompting learners to analyze the samples (linguistic metaphors) that they had gathered and to verbalize (in written form) their thoughts; and (d) to compare and contrast metaphors to those of their L1. HSs were also asked to reflect on metaphoric uses in their heritage dialect. Indeed, introspective and reflective prompts were included in all assignments because they have been identified as a useful language learning tool in SA (Hassall, 2006). In addition, reflections served as a source of data for the analysis of learners' perceptions and self-assessment, as will be noted in the Data Analysis Section below.

Table 1 Metaphor Assignments

\begin{tabular}{|c|c|c|}
\hline Assignment & Pedagogical Objectives & Tasks \\
\hline $\begin{array}{l}\text { Introduction and } \\
\text { Assignment } 1\end{array}$ & $\begin{array}{l}\text { (a) Recognizing what constitutes } \\
\text { metaphor. } \\
\text { (b) Identifying linguistic metaphors } \\
\text { rooted in conceptual metaphors (in } \\
\text { English and Spanish). } \\
\text { (c) Identifying target and source } \\
\text { domains in the formation of conceptual } \\
\text { metaphors. }\end{array}$ & $\begin{array}{l}\text { (a) Introduction to the topic: describing metaphor, understanding its } \\
\text { importance in language learning, defining linguistic and conceptual } \\
\text { metaphors, understanding semantic mapping and domains. } \\
\text { (b) Matching conceptual with linguistic metaphors (in English and } \\
\text { Spanish). } \\
\text { (c) Verbalizing links between conceptual and linguistic metaphors } \\
\text { through the analysis of source and target domains. }\end{array}$ \\
\hline Assignment 2 & $\begin{array}{l}\text { (a) Identifying linguistic metaphors } \\
\text { rooted in conceptual metaphors (in } \\
\text { English and Spanish). } \\
\text { (b) Examining cross-culture and cross- } \\
\text { linguistic comparisons. }\end{array}$ & $\begin{array}{l}\text { (a) Identifying linguistic metaphors. } \\
\text { (b) Matching linguistic with conceptual metaphors. } \\
\text { (c) Discussing cross-cultural and cross-linguistic differences between } \\
\text { English and Spanish (and the heritage dialect, when applicable). } \\
\text { (d) Reporting linguistic metaphors observed during the previous } \\
\text { week. Explaining the conceptual metaphor behind them. }\end{array}$ \\
\hline Assignments 3 and 4 & $\begin{array}{l}\text { (a) Identifying linguistic metaphors } \\
\text { rooted in conceptual metaphors (in } \\
\text { English and Spanish). } \\
\text { (b) Examining cross-culture and cross- } \\
\text { linguistic comparisons. } \\
\text { (c) Promoting the inclusion of metaphor } \\
\text { in productive language. }\end{array}$ & $\begin{array}{l}\text { (a) Reporting linguistic metaphors observed during the previous } \\
\text { week. Explaining the conceptual metaphor behind them. } \\
\text { (c) Discussing cross-cultural and cross-linguistic differences between } \\
\text { English and Spanish (and the heritage dialect, when applicable). } \\
\text { (d) Creating a dialogue with linguistic metaphors identified in a } \\
\text { native speaker's speech. }\end{array}$ \\
\hline
\end{tabular}


Assignment 1 (in Appendix A) was completed during the pre-departure meeting, where the researcher introduced the topic of metaphor and discussed its importance in language learning and use. The rest of the assignments were done online using the university's online platform. The researcher reviewed students' work and provided individualized feedback on a weekly basis, also online or via email. Two recurrent themes in the researcher's feedback included helping learners distinguish linguistic metaphors from idioms and understanding the difference between conceptual and linguistic metaphors.

\section{Participants}

The sA program was five weeks long and took place in Salamanca, Spain. Fifteen students (14 females and one male) from a large regional university in the Midwestern United States were part of this study (see Table 2). They were between 18 and 25 years old. Six participants were Spanish L2 learners and nine were Spanish HSs. HSs are individuals who were raised in a home where a language other than the mainstream language was spoken (Valdés, 2001). HS were of Mexican descent and had either been born in the us or their age of arrival was under 5 years old.

Participants took a proficiency exam at the language academy. Based on the Common European Framework of Reference for Languages levels, ten students were placed at the B2 level (able to achieve most goals and speak in a range of topics), four placed at the B1 level (able to speak in a limited fashion regarding familiar situations and to deal, in general terms, with non-routine information), and two students placed at the A2 level (able to deal with simple information and to communicate in familiar contexts). Students lived with host families. They attended classes at a language academy for 4 to 6 hours a day. As a cohort, they participated in touristic and cultural excursions on weekends.
Table 2 Participants' Profiles

\begin{tabular}{llll}
\hline Participant & Gender & Linguistic Status & $\begin{array}{l}\text { Proficiency } \\
\text { Level }\end{array}$ \\
\hline P1 & F & HS & B2 \\
P2 & F & L2 & B2 \\
P3 & F & HS & B2 \\
P4 & F & HS & B2 \\
P5 & F & L2 & B2 \\
P6 & M & HS & B2 \\
P7 & F & HS & B2 \\
P8 & F & HS & B2 \\
P9 & F & HS & B2 \\
P10 & F & HS & B2 \\
P11 & F & HS & B2 \\
P12 & F & L2 & B1 \\
P13 & F & L2 & B1 \\
P14 & F & L2 & A2 \\
P15 & F & L2 & A2 \\
\hline
\end{tabular}

\section{Language Contact Profile}

Since weekly metaphor assignments encouraged learners to draw samples for analysis from their daily experiences while abroad, the Language Contact Profile or LCP (Freed et al., 2004) was implemented in order to gauge how much contact learners had with the language community. Traditionally, the LCP comprises two instruments: a pre- and post-test. Learners completed the LCP pre-test during their first week abroad; results were reported in 'Participants.' In the LCP posttest, students usually report their activities during their sojourn. However, because it has been suggested that learners' reports may be inaccurate when having to recall their activities abroad from memory (Briggs, 2015), the post-test was adapted so that, besides providing estimates (in hours), participants provided comments on their activities on a weekly basis.

LCP (post-test) results are presented here. Table 3 includes an average for how much time learners allotted to each activity based on their reports for weeks 2, 3, and 4. A descriptive summary of learners' weekly commentary follows. 
Table 3 LCP averages (in hours)

\begin{tabular}{llllll}
\hline Participant & Time in class & Speaking & Reading & Listening & Writing \\
\hline P1 & 18 & 15 & 6 & 2 & 3 \\
P2 & 18 & 10 & 5 & $\mathrm{n} / \mathrm{a}$ & 4 \\
P3 & 24 & 27 & 14 & 5 & 15 \\
P4 & 29 & 41 & 22 & 9 & 2 \\
P5 & 19 & 22 & 10 & 5 & 3 \\
P6 & 18 & 35 & 16 & 20 & 11 \\
P7 & 17 & 55 & 12 & 9 & 10 \\
P8 & 20 & $\mathrm{n} / \mathrm{a}$ & 14 & $\mathrm{n} / \mathrm{a}$ & 10 \\
P9 & 26 & 34 & 11 & 7 & 7 \\
P10 & 21 & 40 & 3 & 2 & 2 \\
P11 & 20 & 15 & 7 & 7 & 5 \\
P12 & 30 & 40 & 20 & 6 & 15 \\
P13 & 19 & 20 & 8 & 4 & 4 \\
P14 & 21 & 9 & 4 & 2 & 4 \\
P15 & 12 & 18 & 20 & 2 & 13 \\
\hline
\end{tabular}

Note: $\mathrm{n} / \mathrm{a}$ means that the learner did not provide an answer.

As seen in Table 3, learners spent the majority of their day attending class and engaged in speaking activities. The qualitative portion of the LCP provides additional details. In regard to interaction with others, learners stated that they had contact mostly with the host-family and teachers. These exchanges were described as superficial and brief in the first week; however, they became more meaningful and involved over time. Contact with other members of the language community was brief and formulaic. Less proficient learners (A2 level) encountered challenges communicating with others. Reading, listening, and writing were confined to a minimum; these skills were used mostly for school-related tasks.

\section{Data Collection and Analysis}

Lafford and Collentine (2006) posited that in order to understand the intricacies of language learning in SA, it is necessary to conduct more studies that utilize qualitative methods of data analysis. Wilkinson (1998), also referring to research on the SA context, noted that qualitative studies enable a valuable understanding of participants' perspective and can open "new avenues of thought and inquiry” (Wilkinson, 1998, p. 24).

Regarding this study's particular focus, metaphor, qualitative methods have also been emphasized. Valeva (1996, p. 35) asserted that "the application of quantitative methods might not be the best and most fruitful way of approaching metaphor, mostly because of the frequent inadequacy of reducing the subjects' answers to the presence or absence of a given semantic information." Thus, considering these arguments, the current study adopted a qualitative method of data analysis that aimed to provide an emic perspective of learners' experiences during SA as they engaged with the subject of metaphor.

Two sources of data were employed for the analysis: (a) learners' reflections completed with their weekly assignments (see Appendix A for sample prompts as part of Assignment 1) and (b) a final questionnaire, which they answered on the fifth and last week abroad (Appendix B). The final questionnaire 
consisted of two sections: an exercise with three linguistic metaphors, in context, that learners analyzed (i.e., explained their figurative meaning and conceptual metaphors). In the second section, they were prompted to reflect, based on the analysis they had just performed, how their understanding of metaphor had changed during SA and as a result of metaphor instruction.

For the analysis of participants' perceptions of metaphor instruction and new understandings gained from it, learners' commentary was divided into portions that were examined over four months and then revisited six months later. With each passing through the data, the researcher sought relevant and recurrent themes that answered the larger question on learners' perceptions of metaphor instruction and gains. In addition, descriptive statistics were introduced, when appropriate, in order to verify and illustrate tendencies, preferences, and patterns observed in learners' commentary (Mackey \& Gass, 2005).

\section{Results}

The analysis of learners' commentary in weekly assignments and the final questionnaire shed light on their perceptions on metaphor instruction and its effectiveness as well as learners' self-reported new understandings on the topic of metaphor in Spanish resulting from their participation in metaphor instruction.

\section{The Effectiveness of Metaphor Instruction in the SA Context}

Ten learners (66\%) observed that the sA context contributed to learning metaphors by making the material more meaningful and personal as they could hear/see metaphors in their surroundings. They observed that, in a classroom setting at the home institution, the subject of metaphor would have been just one more topic covered in class and quickly forgotten and would have been devoid of the cultural constructs that embody metaphors in language. In SA, they were able to connect theory with practice, as explained by $\mathrm{P} 1$ in the next excerpt:

I think that by studying abroad, I was able to understand the metaphors of the specific region I was in. In order to understand the meaning behind these metaphors, you have to understand the culture. (P1, questionnaire, June 28, 2016)

Less proficient learners (A2 level), though, did not feel they benefited from instruction in the SA setting. Instead, they suggested that classroom instruction at the home institution would have been more beneficial. They argued that being less competent in Spanish prevented them from being exposed to metaphor in every-day language, particularly as they compared themselves to the HSs in the group, as seen in P14's comment:

\section{I don't think there would've been much of a difference in regards to metaphors [b] ecause the only times I was exposed to them (with one exception) was in these as- signments. I could've done these assignments in a US classroom or in my house or anywhere really. Perhaps the native speakers were exposed more, but for a per- son who wasn't already fluent, I wasn't affected greatly in understanding metaphors. (P14, questionnaire, June 28, 2016)}

These findings highlight how learners' competence in the target language play a significant role in their readiness to tackle the subject of metaphor. While more advanced learners profited from the SA context in their understanding of metaphor, less proficient learners would have preferred more structured instruction in the classroom setting.

Looking ahead to their return to the United States, eight learners (53\%) stated that they wanted to continue studying metaphors as part of their language learning. However, they added that the exact metaphors they learned through metaphor instruction while in SA were not used back at home where most Spanish speakers are from Latin America. Other learners more forcefully noted that they could never use these metaphors back in the US as others would not understand them. Yet 
others were unsure about future use and thought that, even though these concepts were fresh in their minds now, they would soon forget them due to lack of use and continued focus on the topic in Spanish classes at the home institution. Furthermore, other participants added that these metaphors would not be useful with professors at the home institution who were from different origins or for whom Spanish was their L2.

Less proficient learners concluded that they had not profited from metaphor instruction during SA like their more proficient classmates did, so they did not anticipate any future use. Similarly, HSs had reservations about their continued use of metaphors rooted in Peninsular Spanish and culture. As P9, put it, she would not use what she learned through the assignments because her family is from Mexico and she is interested in the metaphors of Mexican Spanish.

My family is from Mexico and I will use the metaphors from my family's country. [...]. I am communicating with my family and friends [;] it is important that they understand what I am saying. (P9, questionnaire, June 28, 2016)

Seven learners (46\%) emphasized the need to learn to use metaphor in Spanish as they saw it as intrinsically connected to the culture of the target language and inseparable from any linguistic expression, as stated by $\mathrm{P} 7$ :

There are so many metaphors in a language. It helps people connect with and understand an idea that otherwise would be too hard to understand. Metaphors are so common that there is no way one could understand a language well without learning them (P7, questionnaire, June 28, 2016).

\section{Gains Resulting from Metaphor Instruction}

By the end of the program, eleven participants (73\%) indicated that they had gained knowledge and increased awareness of the topic. They attributed these gains to the weekly assignments and their interaction with everything that constituted the SA setting. P2 observed how she and students in her cohort became aware of metaphors and identified them as they came in contact with them on a daily basis.

During these five weeks, I have noticed metaphors more. Now I notice them when I am reading and also in colloquial language. Sometimes when I am with the guys from the group, we say "Metaphor!" when we hear one. I notice them [metaphors] in almost every page in the book I am reading. (P2, questionnaire, June 28, 2016)

One learner stated that she had not yet fully understood the topic, and another reported that she had recently understood the topic but that it had taken her a lot longer than it did her peers. Two HSs purported that they had not noticed much improvement; they believed that this was because they could understand and use the language just fine even before metaphor instruction. Overall, instruction on metaphor was seen positively by students.

Although, at every step of metaphor instruction, learners were encouraged to actively incorporate metaphor in their Spanish, this proved difficult to achieve. In their reports, four learners (26\%) noted that they had been able to use at least one of the metaphors discussed in the assignments during their time abroad. One Hs observed that she had used the expressions that she felt aligned with her heritage language because they felt more natural to her. Other participants (66\%) explained that they had not been able to utilize metaphors in their language production. Their reasons for this varied. One learner explained that she was not proficient enough in the spoken language to produce metaphors and that her focus was still on learning how to conjugate verbs and grammar in general. Most reported that although they could now understand the theory on linguistic metaphors, they were not sure how to incorporate them in their own language production.

Therefore, the analysis of learners' reflections touched upon their perception on the effectiveness of the metaphor intervention and their new 
understandings on the topic of metaphor. Findings suggest that for most learners, instruction was beneficial to their theoretical understanding of metaphor; however, lower proficiency learners believed that, based on their current abilities in Spanish, they would have benefited more from instruction in a classroom setting at the home institution. When reflecting on their gains as a result of instruction, most learners reported being somewhat unable to incorporate in their language the metaphors targeted weekly via instruction. A possible explanation for this limited incorporation of target metaphors in active language might be learners' concerns about the usefulness of the Peninsular Spanish metaphors they were learning once they returned to the United States. Indeed, most HSs showed little interest in the metaphors of a different dialect and culture.

\section{Discussion and Conclusion}

This research reports on Spanish L2 learners and heritage language learners, who completed a study abroad (sA) program in Spain in which language instruction was supplemented with a module on metaphor. The purpose of this article was twofold: to describe the supplementary material targeting metaphor, and to report on learners' perceptions of the pedagogical intervention and new understanding of metaphor in Spanish as a result of their engagement with it.

Metaphor instruction aimed to enhance learners' awareness and understanding of metaphor, particularly by promoting comprehension and noticing of these artifacts in the SA environment. For most learners, this objective was met, even if their contact with the language community was somewhat limited (as reported in Methodology). Most participants had become aware of metaphors in every-day language, although they were not fully able to produce them themselves, and, in many cases, did not believe they wanted to appropriate what they understood to be metaphors exclusive to Peninsular Spanish. These results call for the analysis of metaphor awareness versus metaphoric competence and learners' discernment and preference for adopting or rejecting cultural artifacts associated with a language community.

Metaphor awareness is being able to recognize metaphorical expressions in terms of their linguistic materialization, cross-cultural and cross-linguistic variety, and underlying themes (Boers, 2004). Although much research on metaphor awareness has made vocabulary learning its focus (Hoang, 2014), studies have found that instruction targeting metaphor awareness presents benefits, including increased comprehension of literary readings (Picken, 2005, 2007), cross-linguistic awareness (Sacristán, 2009), and oral comprehension (Littlemore, 2001). Although metaphor awareness does not equal metaphoric competence, it represents a logical first step towards metaphoric competence. From this perspective, and as mentioned before, metaphor instruction in this study appeared to exert the expected benefits.

Even though learners had been instructed on the importance of metaphor and prompted to incorporate such language in their linguistic production (see Table 1, Introduction, Assignments 1, 3, and 4), they struggled to do so. These findings are not surprising since it has been found that even advanced learners tend to avoid using metaphorical senses of words and prefer more literal uses (Littlemore, 2009). In this study, learners reflected that they were not sure how or in which contexts to use metaphor.

In addressing this issue, Littlemore (2009) explained that learners need to develop cognitive fluency, which implies understanding subtle differences in meaning based on discourse settings. The author added that "metaphoric competence does not carry fully-specified meanings; their meaning needs to be 'soft assembled' in real time [...] using contextual cues and drawing on their own encyclopedic knowledge" (Littlemore, 2009, p. 104). Thus, once aware of metaphors, learners need assistance in interpreting context, meanings, and using 
metaphors creatively and in a dynamic setting where they grow confident in their use.

Another matter that challenged learners' use of metaphor was their concern that the metaphors targeted in instruction were solely connected to Peninsular Spanish. HSs expressed interest in the metaphors of the dialect spoken by their families only. The study by Ringer-Hilfinger (2012) resonates with this finding. In her study, students became aware of dialectal variation in Spain, but their acquisition of the target feature was inconsistent. The author found a correlation with participants' affinity with Latin American variations in the Us to be a factor in (non) acquisition and concluded that learners' preferences were determined by the dialect of the native speakers they were in contact with before and after SA. Thus, although instruction in the current study targeted the linguistic and conceptual metaphors of the language community that learners would come in contact with during SA, their own linguistic preferences made metaphoric samples from Peninsular Spanish inconsequential.

While most learners in this study welcomed and reported benefits from metaphoric instruction, less proficient learners struggled with the assignments and believed that instruction at the home institution would have been more beneficial. In regard to the role of language proficiency in metaphor teaching and learning, this finding is somewhat contrary to conclusions in Johnson and Rosano (1993), which argued that metaphoric interpretation was not linked to language abilities. However, this finding does agree with Boers (2004), who postulated that lower proficiency learners struggle to even apply a strategy of metaphor awareness because they lack the vocabulary necessary to understand the statement. Results from this investigation would suggest that more proficient learners are indeed more able to access metaphor in SA, while lower proficiency learners are less able to divert their attention to matters beyond meaning (Lafford \& Collentine, 2006).
Several pedagogical implications are drawn from these results. Firstly, learners had little interest in appropriating metaphors that they associated with Peninsular Spanish. In honoring learners' autonomy (Benson, 2001), it is important to identify the dialect they identify with and shape instruction based on those preferences. Thus, if metaphor instruction is part of a SA experience that does not match learners' preferred dialect, metaphor instruction can be adapted. It can address cross-variation comparisons between dialects and emphasize metaphors shared across Spanish dialects.

Secondly, in terms of proficiency, while more advanced learners profited from metaphor instruction, less proficient learners did not appear to achieve the same gains. Thus, the subject and tasks need to be made more accessible to lower proficiency learners (Lantolf \& Bobrova, 2014; Segalowitz et al., 2004). Two ways in which this can be accomplished are, first, to introduce learners to authentic language via corpus data or even media samples (e.g., podcast) and carrying out systematic and guided analyses of metaphoric language, and, second, to start implementing these practices prior to SA.

Thirdly, although s A programs, are often designed with a Spanish L2 learner in mind, with the growing number of Hss in language classrooms in the US, it is not surprising that HSs would have a growing presence in SA programs. In fact, in this research, most participants were HSs; however, there were no components of the language learning experience that acknowledged HSs' linguistic needs.

In regard to metaphor instruction in particular, the experience reported here suggests that HSs may already be using metaphoric language that they have appropriated from the language learning environment that they were raised in but are not aware of it; and, because of how they learned the language, they might have a passive understanding of metaphor but not enough experience or confidence to use it. Thus, instruction for HSs needs to acknowledge that these learners, unlike Spanish L2 learners, are 
already part of a Spanish language community; instruction should focus on making metaphor salient to them and creating a safe setting where they can creatively use metaphors in their own language production.

Lastly, as seen in this research, learners had limited contact with the language community; and, as stated by Gibbs (1997), metaphor competence comes with experience with the language community. Several researchers have recommended ways to further integrate SA participants by, for example, participating in volunteer work and service-learning and deepening connections with the host-family (Baker-Smemoe et al., 2014; Goldoni, 2013; Knight \& Schmidt-Rinehart, 2002).

Two limitations to this investigation are instruction and feedback, which were only provided electronically (via web or email), and the workload that the culture module added to students' SA coursework. Since the researcher did not travel abroad with the students, she was only able to provide instruction and feedback electronically. Instruction quality could have been improved through the provision of appropriate face-to-face scaffolding (Littlemore, 2004) and on-site guidance and mentoring as learners navigated interactions with the language community. Also, assignments for metaphor instruction were in addition to learners' classwork at the language academy. This often caused learners to feel overwhelmed with the extra work. Based on the study by Knight and Schmidt-Rinehart (2002), participants respond better when extra curriculum is integrated into the SA classwork.

Results from this exploratory study can serve as a point of departure for future research. A future project might consider how metaphoric awareness, as a building block to metaphoric competence, fosters an understanding of conceptual metaphors in the target language. Moreover, although the language acquisition literature provides a clear picture of how L2 learners navigate metaphor, this same level of knowledge is absent when it comes to HSs. Several questions remain to be explored regarding these learners, for instance, how ubiquitous metaphor is in HSs' language production and how able these learners are in comprehending versus producing the metaphors of their heritage culture. Lastly, future research should continue to explore how linguistic metaphors gained during sA might aid in reconceptualizing learners' target language conceptual system.

In sum, this article described a teaching module on metaphor and explored how Spanish learners' (HSs and L2s) perceived the instruction and enhanced contact with metaphor during $\mathrm{SA}$, and linguistic gains resulting from it. Based on learners' reports, metaphor instruction was instrumental in promoting metaphoric awareness; however, learners found themselves limited in their ability to produce metaphoric language. Moreover, lower proficiency learners argued that they would have benefited more from instruction at the home university rather than in SA because they had difficulty capturing metaphor from everyday language as their more proficient peers did. Heritage speakers appeared to be more interested in the metaphors of their home culture than those of the host country. Based on these findings, pedagogical implications addressed ways in which metaphor instruction can bridge metaphoric awareness with metaphoric production and meet the needs of L2 learners and heritage speakers.

\section{References}

Baker-Smemoe, W., Dewey, D. P., Bown, J., \& Martinsen, R. A. (2014). Variables affecting L2 gains during study abroad. Foreign Language Annals, 47(3), 464-486. https://doi.org/10.1111/flan.12093

Benson, P. (2001). Teaching and researching autonomy in language learning ( $2^{\text {nd }} \mathrm{Ed}$.). Routledge.

Boers, F. (2004). Expanding learners' vocabulary through metaphor awareness: What expansion, what learners, what vocabulary (pp. 211-232). In M. Archard \& S. Niemeier(Eds.), Cognitivelinguistics, secondlanguage acquisition and foreign language teaching. De Gruyter. https://doi.org/10.1515/9783110199857.211 
Briggs, J. (2015). A context-specific research tool to probe the out-of-class vocabulary-related strategies of study abroad learners. International Journal of Applied Linguistics, 25(3), 293-314. https://doi. org/10.1111/ijal.12070

Danesi, M. (1995). Learning and teaching languages: The role of "conceptual fluency." International Journal of Applied Linguistics, 5(1), 3-19. https://doi. org/10.1111/j.1473-4192.1995.tb00069.x

Doiz, A., \& Elizari, C. (2013). Metaphoric competence and the acquisition of figurative vocabulary in foreign language learning. Estudios de Lingüistica Inglesa Aplicada, 13, 47-82.

Freed, B., Dewey, D., Segalowitz, N., \& Halter, R. (2004). The language contact profile. SSLA, 26, 349-356. https://doi.org/10.1017/S027226310426209X

Gibbs, R. (1997). Taking metaphor out of our heads and putting it into the cultural world (pp. 145-166). In Selected Papers from the $5^{\text {th }}$ International Cognitive Linguistics Conference. Metaphor in cognitive linguistics. John Benjamins. https://doi.org/10.1075/ cilt.175.09gib

Goldoni, F. (2013). Students' immersion experiences in study abroad. Foreign Language Annals, 46(3), 359 376. https://doi.org/10.1111/flan.12047

Hassall, T. (2006). Learning to take leave in social conversations: A diary study (pp. 31-58). In M. DuFon \& E. Churchill (Eds.), Language learners in study abroad contexts. Multilingual Matters. https://doi. org/10.21832/9781853598531-006

Hoang, H. (2014). Metaphor and second language learning: The state of the field. TESL-EJ, 18(2), 1-27.

Johnson, J., \& Rosano, T. (1993). Relation of cognitive style to metaphor interpretation and second language proficiency. Applied Psycholinguistics, 14(2), 159-175. https://doi.org/10.1017/S014271640000953X

Knight, S. M., \& Schmidt-Rinehart, B. C. (2002). Enhancing the Homestay: Study Abroad from the Host Family's Perspective. Foreign Language Annals, 35(2), 190201. https://doi.org/10.1111/j.1944-9720.2002. tb03154.x

Koike, D., \& Lacorte, M. (2014). Toward intercultural competence: From questions to perspectives and practices of the target culture. Journal of Spanish Language Teaching, 1(1), 15-30. https://doi.org/10 $.1080 / 23247797.2014 .898497$

Kövecses, Z., \& Szabó, P. (1996). Idioms: A view from cognitive semantics. Applied Linguistics, 17(3), 326355. https://doi.org/10.1093/applin/17.3.326
Kramsch, C. (1998). Language and culture. Oxford University Press.

Lafford, B., \& Collentine, J. (2006). The effects of study abroad and classroom contexts on the acquisition of Spanish as a second language; from research to application. In R. Salaberry \& B. Lafford (Eds.), The art of teaching Spanish: Second language acquisition from research to praxis (pp. 103-126). Georgetown University Press.

Lakoff, G., \& Johnson, M. (2003). Metaphors we live by. The University of Chicago Press. https://doi. org/10.7208/chicago/9780226470993.001.0001

Lantolf, J. (1999). Second culture acquisition: Cognitive considerations. In E. Hinkel (Ed.), Culture in language teaching and learning (pp. 28-46). Cambridge University Press.

Lantolf, J. (2006). Sociocultural theory and L2, state of the art. Studies in Second Language Acquisition, 28, 67-109. https://doi.org/10.1017/ S0272263106060037

Lantolf, J., \& Bobrova, L. (2014). Metaphor instruction in the L2 Spanish classroom: Theoretical argument and pedagogical program. Journal of Spanish Language Teaching, 1(1), 46-61. https://doi.org/10.108 $0 / 23247797.2014 .898515$

Lantolf, J., \& Thorne, S. (2006). Symbolic mediation and L2 learners: Metaphor, lexis, and narratives. In Sociocultural theory and the genesis of second language development (pp. 113-150). Oxford University Press.

Littlemore, J. (2001). The use of metaphor in university lecturesand the problems thatitcausesforoverseasstudents. Teaching in Higher Education, 6(3), 333-349. https://doi.org/10.1080/13562510120061205

Littlemore, J. (2004). Interpreting metaphors in the EFL classroom. Les Cahiers de l'APLIUT, 23(2), 57-70. https://doi.org/10.4000/apliut.3339

Littlemore, J. (2009). Applying cognitive linguistics to second language learning and teaching. Palgrave Macmillan. https://doi.org/10.1057/9780230245259

Littlemore, J., \& Low, G. (2006). Metaphoric competence, second language learning, and communicative language ability. Applied Linguistics, 27(2), 268-294. https://doi.org/10.1093/applin/aml004

Mackey, A., \& Gass, S. (2005). Second language research: Methodology and design. Routledge.

Nguyen, H. T., \& Kellogg, G. (2010). "I had a stereotype that American were fat": Becoming a speaker of culture in a second language. Modern 
Language Journal, 94(1), 56-73. https://doi. org/10.1111/j.1540-4781.2009.00983.x

Picken, J. (2005). Helping foreign language learners to make sense of literature with metaphor awareness-raising. Language Awareness, 14(2-3), 142-152. https://doi. org/10.1080/09658410508668830

Picken, J. (2007). Literature, metaphor and the foreign language learner. Palgrave Macmillan. https://doi. org/10.1057/9780230591608

Reynolds-Case, A. (2013). The value of short-term study abroad: An increase in students' cultural and pragmatic competency. Foreign Language Annals, 46(2), 311-322. https://doi.org/10.1111/flan.12034

Ringer-Hilfinger, K. (2012). Learner acquisition of dialect variation in a study abroad context: The case of the Spanish theta. Foreign Language Annals, 45(3), 430-446. https://doi. org/10.1111/j.1944-9720.2012.01201.x

Sacristán. (2009). A translation approach to metaphor teaching in the LSP classroom: Sample exercises from a business English syllabus. Ibérica, 17, 83-98.

Segalowitz, N., Freed, B., Collentine, J., Lafford, B., \& Díaz-Campos, M. (2004). A comparison of Spanish second language acquisition in two different learning contexts: Study abroad and the domestic classroom. Frontiers: The Interdisciplinary Journal of Study Abroad, 10, 1-18. https://doi.org/10.36366/ frontiers.v10i1.130

Strange, H., \& Gibson, H. (2017). An investigation of experiential and transformative learning in study abroad programs. Frontiers: The Interdisciplinary Journal of Study Abroad, 29(1), 85-100. https://doi. org/10.36366/frontiers.v29i1.387

Valdés, G. (2001). Learning and not learning English: Latino students in American schools. Teachers College Press.

Valeva, G. (1996). On the notion of conceptual fluency in a second language. In A. Pavlenko, \& R. Salaberry (Eds.), Cornell working papers in linguistics: Papers in second language acquisition and bilingualism (pp. 22-38). Cornell University Press

Wang, C. (2010). Toward a second language socialization perspective: Issues in study abroad research. Foreign Language Annals, 43(1), 50-63. https://doi. org/10.1111/j.1944-9720.2010.01059.x

Wilkinson, S. (1998). Study abroad from the participants' perspective: A challenge to common beliefs. Foreign Language Annals, 31(1), 23-39. https://doi. org/10.1111/j.1944-9720.1998.tb01330.x

\section{Appendix A. Sample assignment (Assignment 1)}

\section{Metaphors in Everyday Language}

Metaphors enable us to think, understand, and talk about abstract phenomena, such as time, emotions, and moral values in terms of more concrete entities.

For example, the conceptual metaphor TIME ELAPSING IS TRAVEL is shared by all of us 'mentally' and allows us to say and understand linguistic expressions such as "Christmas is coming" (Llega pronto la Navidad) even though Christmas is not a moving object that can travel (as in the expression 'a car is coming'). Thus, in our minds, we perceive the passing of time as physical movement in space.

Other examples related to time include:

- TIME IS AN OBJECT: "We lost time getting home because I couldn't find my keys"

- TIME IS MONEY/ A VALUABLE COMMODITY: “This cost us too much”

These conceptual metaphors also work in Spanish! 
- TIME IS AN OBJECT: "Se ha quedado un largo tiempo en Europa" (she has stayed a long time in Europe)

- TIME IS MONEY/ A VALUABLE COMMODITY: "Esto es algo que cuesta tiempo y dinero" (this is something that costs time and money)

However, not all conceptual metaphors are shared by English and Spanish.

- TIME IS FOOD: "His lack of planning ate up considerable time"

This conceptual metaphor does not exist in Spanish.

How do conceptual metaphors come to be?

There are generalizing principles that are the basis for the formation of metaphors: conceptual mappings. Conceptual mappings are part of the cognitive system that underlies a language. The mappings originate in the correspondence we perceive between the two domains brought into contact in the linguistic metaphor. These mappings allow us to reason about one domain (target domain), usually abstract, in terms of another domain (source domain), usually concrete.

The metaphor works by connecting features of the source domain (concrete) onto the target domain (abstract). Here, the passage of time is understood as an object that travels/moves.

\section{TIME ELAPSING IS TRAVELING}

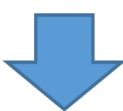

Target domain

"Winter has arrived"

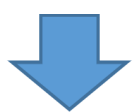

Source domain

"Llegó el invierno"

Conceptual metaphors exist in the mind. When we refer to them, we usually write them in ALL CAPS to identify them as such.

Linguistic metaphors are the actual linguistic expressions (sets of words) that people produce when speaking and are constructed based on the conceptual metaphors that exist in the mind.

Practice A. Match the conceptual metaphor with the linguistic metaphor that best represents it.

\begin{tabular}{ll}
\hline CONCEPTUAL METAPHORS residing in the mind & Linguistic metaphors expressed in actual language \\
\hline 1. MORE IS UP & "she has big ideas" \\
2. LESS IS DOWN & "today is your big day" \\
3. AN ANGRY PERSON IS A PRESSURIZED CONTAINER & "he scored a knockout over his opponent" \\
4. INTENSITY IS HEAT & "he was boiling with anger" \\
5. SIGNIFICANCE IS LARGE & "the man is burning with desire" \\
6. POLITICS IS BOXING & "la temperatura baja en invierno" \\
7. ANGER IS HEATED LIQUID IN A CONTAINER & "The temperature rises in the summer"
\end{tabular}


Practice A. Match the conceptual metaphor with the linguistic metaphor that best represents it. (Cont.)

\begin{tabular}{ll}
\hline CONCEPTUAL METAPHORS residing in the mind & Linguistic metaphors expressed in actual language \\
\hline "hervía de la rabia" & "he was bursting with anger" \\
"estalló en cólera" \\
"he is really steamed" \\
"he let off steam" \\
\hline
\end{tabular}

Now we'll focus only on Spanish. Consider the conceptual metaphor HAPPINESS IS A VALUABLE OBJECT...

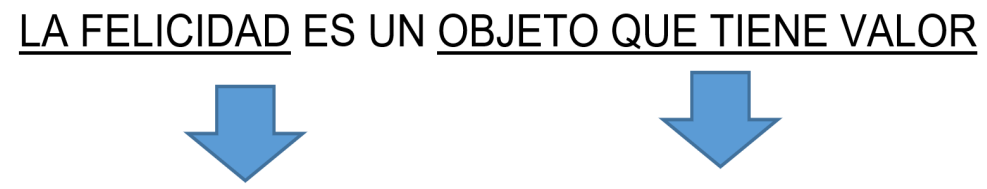

Target domain $\quad$ Source domain

Example:

Conceptual metaphor: LA FELICIDAD ES UN OBJETO QUE TIENE VALOR

Linguistic expression: Es una tragedia terrible que les robó la felicidad. (It is a terrible tragedy that robbed them of happiness)

Figurative meaning: Happiness is a valuable object, thus, an unfortunate event can 'steal' or take away a person's capacity to be or feel happy

Practice B. Conceptual metaphors might vary in the Spanish speaking world. Now, we'll focus on expressions used in Peninsular Spanish. Explain the figurative meaning of the following examples:

Example 1:

Conceptual metaphor: CRITICISM IS GREEN

Linguistic expression: Con esa actitud no le va a ir muy bien en la empresa, pone verde a todos sus compañeros de oficina delante del jefe. (With that attitude, he's not going to do well at the company, he makes his coworkers green in front of the boss=literal translation!)

Figurative meaning: The expression 'poner verde a alguien' means ....

Example 2:

Conceptual metaphor: AN ANGRY PERSON IS A GOAT / TO BECOME ANGRY IS

TO BECOME A GOAT / TO BE ANGRY IS TO BE GOATLIKE 
Linguistic expression: $\underline{\text { Se cabreó porque no le dan el crédito que necesita para pagar la universidad. (She }}$ became like a goat because they didn't give her the loan she needed to pay for school)

Figurative meaning: The expression 'cabrearse' means...

\section{Final reflection:}

1. Were you familiar with the concept of metaphor (as seen in this hand-out) before?

2. Looking back at the examples above, were you familiar with these expressions in Spanish (e.g., cabrearse, poner verde a alguien)?

3. If you are a Spanish heritage speaker (you were raised speaking Spanish), have you used these same expressions we saw before in your Spanish dialect? If not, what are their equivalents?

\section{Appendix B}

\section{Final Assessment}

Part 1. Provide an analysis for each excerpt where you detail what the linguistic and conceptual metaphors are, and what the figurative meaning is.

1. "Estaba como un tren y todos nos quedamos extasiados mirando sus formas voluptuosas y exageradas tetas, que parecían de 'comic"”* (sample item)

\section{Part 2. Reflection.}

1. In light of the analysis you provided in the previous section, how has your awareness and understanding of the subject of metaphor evolved over the course of your study abroad (SA)?

2. During weekly assignments, you have reported many linguistic metaphors,

(a) were you able to use them in your own interactions with others?

(c) will you continue to use them in the future with family, friends, and in (home institution) classes?

* I. Orduna (2013, June 18). Mi vida en rojo [Web log comment]. Retrieved from http://www.mividaenrojo.com/2013/06/todo-al-rojo.html?m=1

How to reference this article: Tocaimaza-Hatch, C. (2020). Instruction on metaphors during a studyabroad program: Students' perceptions and understandings. Íkala, Revista de Lenguaje y Cultura, 25(3), 625-642. https:/doi.org/10.17533/udea.ikala.v25n03a08 